\title{
Occurrence of Globodera artemisiae (Eroshenko et Kazachenko, 1972) Behrens, 1975 and Globodera millefolii (Kirjanova et Krall, 1965) Behrens, 1975 in crop fields in Poland
}

\author{
Występowanie Globodera artemisiae (Eroshenko et Kazachenko, 1972) \\ Behrens, 1975 i Globodera millefolii (Kirjanova et Krall, 1965) \\ Behrens, 1975 na polach uprawnych na terytorium Polski
}

\author{
Witold Karnkowski*, Anna Rosińska
}

\begin{abstract}
Summary
Cyst nematodes Globodera artemisiae (Eroshenko et Kazachenko, 1972) Behrens, 1975 and Globodera millefolii (Kirjanova et Krall, 1965) Behrens, 1975 developing on plants from the Asteraceae family are morphologically similar to potato cyst nematodes Globodera rostochiensis (Wolleneber) Skarbilovich and Globodera pallida (Stone) Behrens, which are serious, quarantine pests of potatoes and other solanaceous plants. The total of 265,855 soil and growing substrate samples were taken by the State Plant Health and Seed Inspection Service (SPHSIS) during official controls of occurrence of the potato cyst nematodes over the period $2010-2015$. The performed laboratory analyses showed that G. artemisiae was detected in 42 samples $(0.016 \%)$, whereas $G$. millefolii in 1 sample $(0.0004 \%)$. For comparison, presence of $G$. rostochiensis was found in 1,228 samples $(0.46 \%)$, and G. pallida in 2 samples $(0.0008 \%)$. The samples containing $G$. artemisiae and G. millefolii constituted $3.34 \%$ of all the samples with viable cysts from Globodera genus. For the first time in Poland, the occurrence of G. millefolii in Świętokrzyskie Voivodeship was detected using molecular methods.
\end{abstract}

Key words: Globodera artemisiae; Globodera millefolii; Poland

\section{Streszczenie}

Mątwiki Globodera artemisiae (Eroshenko et Kazachenko, 1972) Behrens, 1975 i Globodera millefolii (Kirjanova et Krall, 1965) Behrens, 1975 rozwijające się na roślinach z rodziny Asteraceae, wykazują morfologiczne podobieństwo do mątwików tworzących cysty na ziemniaku - mątwika ziemniaczanego, Globodera rostochiensis (Wolleneber) Skarbilovich i mątwika agresywnego, Globodera pallida (Stone) Behrens, które są groźnymi, kwarantannowymi szkodnikami ziemniaka i innych roślin psiankowatych. Podczas kontroli występowania mątwików tworzących cysty na ziemniaku, prowadzonych przez Państwową Inspekcję Ochrony Roślin i Nasiennictwa w latach 2010-2015, pobrano i poddano analizom laboratoryjnym łącznie 265855 próbek gleby i podłoży. W 42 próbkach (0,016\%) stwierdzono obecność gatunku G. artemisiae, natomiast w 1 próbce $(0,0004 \%)$ obecność gatunku G. millefolii. Dla porównania, obecność gatunku G. rostochiensis stwierdzono w 1228 próbkach $(0,46 \%)$, a G. pallida w 2 próbkach (0,0008\%). Próbki, w których stwierdzono występowanie gatunków G. artemisiae i G. millefolii stanowiły 3,34\% ogółu próbek, w których stwierdzono obecność cyst mątwików z rodzaju Globodera z żywą zawartością. Wykrycie gatunku G. millefolii na terenie województwa świętokrzyskiego jest przypadkiem wykrycia tego gatunku w Polsce po raz pierwszy udokumentowanym metodami molekularnymi.

Słowa kluczowe: Globodera artemisiae; Globodera millefolii; Polska

Główny Inspektorat Ochrony Roślin i Nasiennictwa

Centralne Laboratorium

Żwirki i Wigury 73, 87-100 Toruń

*corresponding author:w.karnkowski@piorin.gov.pl 


\section{Wstęp / Introduction}

Mątwiki: Globodera artemisiae (Eroshenko et Kazachenko, 1972) Behrens, 1975 i Globodera millefolii (Kirjanova et Krall, 1965) Behrens, 1975 są nicieniami rozwijającymi się na roślinach z rodziny Asteraceae (złożone) (Brzeski 1998; Dobosz i wsp. 2013). Zgodnie z aktualną systematyką rodzaju Globodera (Subbotin i wsp. 2010), gatunek G. millefolii, który został opisany na podstawie morfologii jednej samicy rozwijającej się na korzeniach krwawnika, stwierdzonej w Tallinie, Estonia (Kirjanowa i Krall 1965) jest tożsamy $\mathrm{z}$ gatunkiem G. achilleae (Golden et Klindić, 1973) Behrens, 1975 opisanym po raz pierwszy w Bośni (Golden i Klindić 1973) i wykazywanym także $z$ terenu Polski (Brzeski 1998). G. achilleae jest wcześniejszym synonimem nazwy G. millefolii. G. millefolii wykazuje podobieństwo morfologiczne do mątwików tworzących cysty na ziemniaku, tj. mątwika ziemniaczanego, Globodera rostochiensis (Wolleneber, 1923) Skarbilovich, 1959 i mątwika agresywnego, Globodera pallida (Stone, 1973) Behrens, 1975, które są groźnymi szkodnikami ziemniaka i innych roślin psiankowatych podlegającymi obowiązkowi zwalczania. Podobieństwo morfologiczne do tych gatunków wykazuje także G. artemisiae. Stąd niezbędna jest poprawna identyfikacja cyst mątwików z rodzaju Globodera stwierdzanych w próbkach gleby pobieranych w ramach kontroli występowania na terytorium kraju mątwików tworzących cysty na ziemniaku.

Celem badań było ustalenie częstotliwości występowania $G$. artemisiae i $G$. millefolii w próbkach gleby i podłoży pobranych na terytorium Polski przez Państwową Inspekcję Ochrony Roślin i Nasiennictwa w latach 2010-2015.

\section{Materiały i metody / Materials and methods}

Badaniom zostały poddane cysty mątwików z żywą zawartością (tj. zawierające jaja lub osobniki młodociane) wyizolowane $\mathrm{z}$ próbek gleby pobranych na terenie całego kraju przez inspektorów Państwowej Inspekcji Ochrony Roślin i Nasiennictwa (PIORiN) w ramach kontroli występowania mątwików tworzących cysty na ziemniaku. W pierwszej kolejności dokonano identyfikacji gatunków na podstawie szczegółowej analizy diagnostycznych cech morfologicznych i morfometrycznych wyizolowanych cyst oraz znajdujących się w cystach osobników młodocianych, w oparciu o dane literaturowe (Brzeski 1998; Karnkowski 2006; OEPP/EPPO 2009; Subbotin i wsp. 2010; OEPP/ /EPPO 2013).

W kolejnym etapie, wynik identyfikacji nicieni o cechach morfologicznych $G$. rostochiensis i $G$. pallida weryfikowano z zastosowaniem testu multiplex PCR (Polymerase Chain Reaction - reakcja łańcuchowa polimerazy) według Bulmana i Marshalla (1997), przy użyciu starterów ITS5, PITSr3 oraz PITSp4 (Karnkowski i wsp. 2015). Dla potwierdzenia wyniku identyfikacji G. pallida, przeprowadzono dodatkowo test PCR według Zouhara i wsp. (2000), z użyciem starterów UNI, GRO1, GPA oraz test PCR-RFLP (Polymerase Chain Reaction - Restriction
Fragment Length Polymorphism - reakcja łańcuchowa polimerazy - polimorfizm długości fragmentów restrykcyjnych) według Thiéry i Mugniéry (1996) z zastosowaniem starterów $18 \mathrm{~S}$ oraz $26 \mathrm{~S}$ i endonukleazy restrykcyjnej Bsh 1236 I (Karnkowski i wsp. 2011).

Po wykluczeniu przynależności nicieni do gatunków G. rostochiensis lub G. pallida, przeprowadzono ich dalszą identyfikację do gatunku $G$. artemisiae, z zastosowaniem testu PCR-RFLP (Karnkowski i wsp. 2015). Jeśli wyniki testów nie potwierdziły przynależności nicieni do gatunku G. artemisiae, przeprowadzono ich identyfikację z zastosowaniem testu PCR-RFLP według Širca i wsp. (2010) w celu potwierdzenia przynależności nicieni do gatunku G. millefolii (wymienionego w tej pracy pod nazwą G. achilleae). Aby jednoznacznie zidentyfikować nicienie do tego gatunku, produkt PCR $\mathrm{z}$ wyizolowanego DNA (deoxyribonucleic acid) poddano sekwencjonowaniu. Wykonawcą sekwencjonowania była firma „Genomed" (Warszawa, ul. Ponczowa 12). Reakcje sekwencjonowania przeprowadzane były przy użyciu zestawu BigDye ${ }^{\circledR}$ Terminator v3.1 firmy Applied Biosystems (Life Technologies). Produkty reakcji sekwencjonowania rozdzielano w sekwenatorze kapilarnym 3730xl DNA Analyzer. Analizę porównawczą uzyskanej sekwencji DNA wykonywano za pomocą narzędzia BLAST (Basic Local Alignment Search Tool) w bazie NCBI (National Center for Biotechnology Information - Narodowe Centrum Informacji Biotechnologicznej).

\section{Wyniki i dyskusja / Results and discussion}

Podczas kontroli występowania mątwików tworzących cysty na ziemniaku prowadzonych przez PIORiN w latach 2010-2015 pobrano i poddano analizom laboratoryjnym łącznie 266855 próbek gleby i podłoży. W 42 próbkach $(0,016 \%)$ pochodzących $\mathrm{z}$ terenu województw: kujawsko-pomorskiego, mazowieckiego, podlaskiego, pomorskiego i warmińsko-mazurskiego stwierdzono obecność gatunku G. artemisiae, natomiast w 1 próbce $(0,0004 \%) \mathrm{z}$ terenu województwa świętokrzyskiego - obecność gatunku G. millefolii. Najważniejsze z punktu widzenia poprawnej identyfikacji nicieni wymiary oraz cechy morfologiczne gatunków G. artemisiae i G. millefolii z zebranych populacji przedstawiono $\mathrm{w}$ tabeli 1 . oraz zilustrowano na rysunkach 1 i 2.

Gatunek $G$. artemisiae był wykazywany z terytorium Polski przez różnych autorów (Brzeski 1998; Dobosz i wsp. 2008, 2013). Brzeski (1998) wykazał także obecność w Polsce G. achilleae, choć kształt przedniej powierzchni guzików sztyletu osobników młodocianych nicieni opisanych $\mathrm{w}$ tej publikacji (znacznie wgłębiona) odbiega od podanego w oryginalnym opisie $G$. achilleae przez Golden i Klindić (1973) (spłaszczona i zaokrąglona). Dobosz i wsp. (2013) charakteryzują gatunek G. millefolii, a opis i fotografie zamieszczone w tej publikacji oparte są na wykonanych przez prof. Brzeskiego preparatach gatunku zidentyfikowanego jako $G$. achilleae, obecnie zsynonimizowanego z G. millefolii. Praca Dobosz i wsp. (2013) zawiera analizę cech morfologicznych nicieni bez przeprowadzania testów molekularnych. Kształt guzików sztyletu 
Tabela 1. Wartości parametrów cech diagnostycznych Globodera artemisiae i Globodera millefolii (wartości średnie i zakresy)

Table 1. Values of parameters of diagnostic characters for Globodera artemisiae and Globodera millefolii (ranges and means)

\begin{tabular}{|c|c|c|}
\hline $\begin{array}{l}\text { Cechy morfologiczne } \\
\text { Morphological characters }\end{array}$ & Globodera artemisiae* & Globodera millefolii ${ }^{* *}$ \\
\hline \multicolumn{3}{|l|}{ Cysty-Cysts } \\
\hline $\begin{array}{l}\text { Średnica okienka } \\
\text { Fenestral diameter }[\mu \mathrm{m}]\end{array}$ & $\begin{array}{c}15-38 \\
(21,25-25)\end{array}$ & $20-25$ \\
\hline $\begin{array}{l}\text { Odległość okienka wulwalnego od odbytu } \\
\text { Distance between vulval fenestra and anus }[\mu \mathrm{m}]\end{array}$ & $\begin{array}{c}23-65 \\
(28,5-46)\end{array}$ & $29-35$ \\
\hline $\begin{array}{l}\text { Indeks Graneka } \\
\text { Granek's ratio }\end{array}$ & $\begin{array}{c}0,7-4,5 \\
(1,47-1,76) \\
\end{array}$ & $1,4-1,5$ \\
\hline $\begin{array}{l}\text { Liczba fałdów między okienkiem wulwalnym a odbytem } \\
\text { Number of cuticular rifges between fenestra and anus }\end{array}$ & $\begin{array}{l}4-12 \\
(7-9)\end{array}$ & $6-7$ \\
\hline \multicolumn{3}{|c|}{ Osobniki młodociane $\mathrm{J}_{2}-\mathrm{J}_{2}$ juveniles } \\
\hline $\begin{array}{l}\text { Długość sztyletu } \\
\text { Stylet length }[\mu \mathrm{m}]\end{array}$ & $\begin{array}{c}19-25 \\
(20,4-25,4)\end{array}$ & $\begin{array}{l}24-27 \\
(25,4)\end{array}$ \\
\hline $\begin{array}{l}\text { Szerokość i kształt przedniej powierzchni guzików sztyletu } \\
\text { Width and shape of stylet knobs }[\mu \mathrm{m}]\end{array}$ & $\begin{array}{c}3-4 \\
\text { zaokrąglona } \\
\text { rounded }\end{array}$ & $\begin{array}{l}4-5 \\
\text { spłaszczona i zaokrąglona } \\
\text { flattened and rounded }\end{array}$ \\
\hline $\begin{array}{l}\text { Długość ogona } \\
\text { Tail length }[\mu \mathrm{m}]\end{array}$ & $\begin{array}{c}35-58 \\
(44-53,5)\end{array}$ & $\begin{array}{c}39-52 \\
(48)\end{array}$ \\
\hline $\begin{array}{l}\text { Długość przezroczystej części ogona } \\
\text { Hyaline tail part length }[\mu \mathrm{m}]\end{array}$ & $\begin{array}{c}17-31 \\
(21-27,25)\end{array}$ & $\begin{array}{l}23-30 \\
(27,2)\end{array}$ \\
\hline
\end{tabular}

*zakres i () zakres wartości średnich uzyskany dla materiału wyizolowanego ze wszystkich 42 badanych próbek (74 cysty i 165 osobników młodocianych) - ranges and () ranges of means obtained for the material isolated from all 42 tested samples (74 cysts i 165 juveniles)

**dane dla 2 wyizolowanych cyst i 10 osobników młodocianych - data for 2 isolated cysts and 10 juveniles
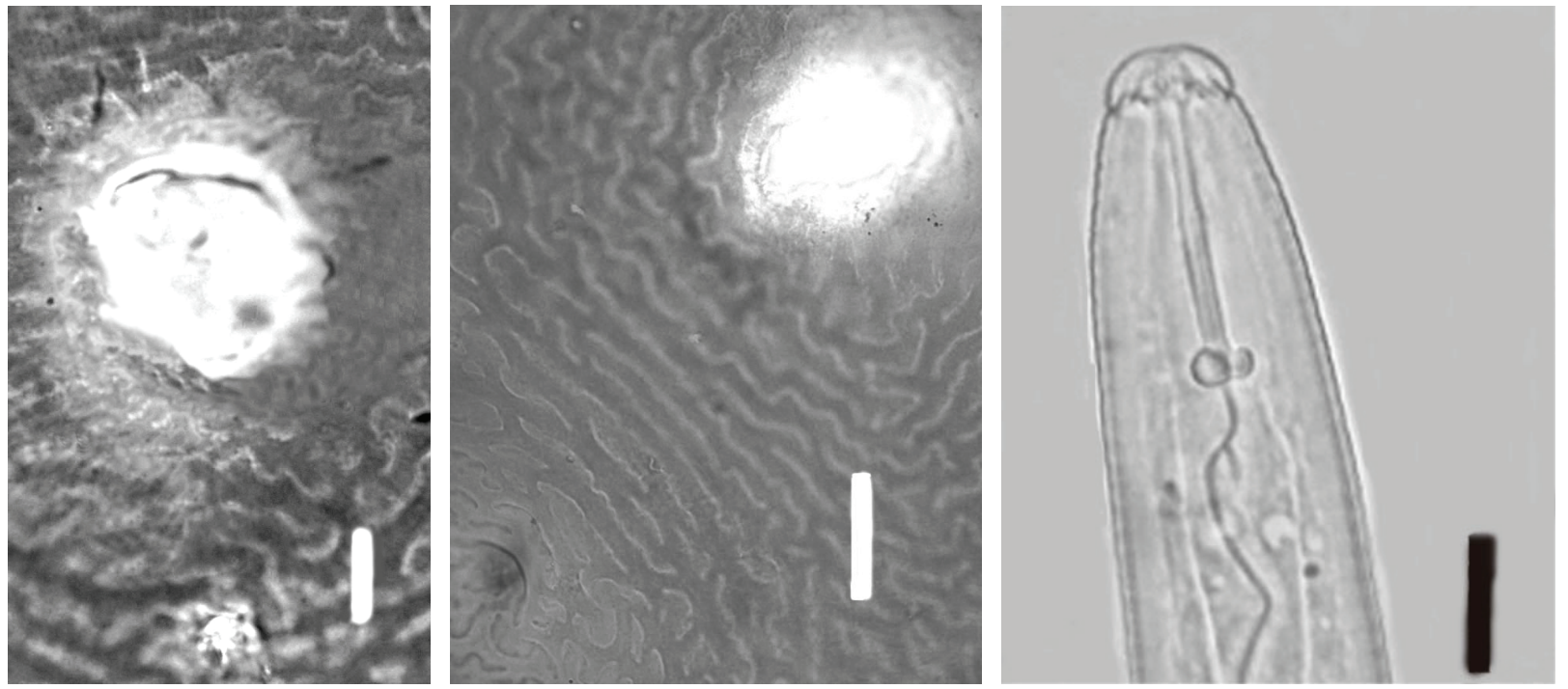

Rys. 1. Okolice wulwy i odbytu cysty (po lewej i w środku - widoczna zmienność cech morfologicznych u różnych cyst) oraz przednia część ciała osobnika młodocianego $\mathrm{J}_{2}$ (po prawej) Globodera artemisiae (skala wielkości $=10 \mu \mathrm{m}$ )

Fig. 1. The area of fenestra and anus of cyst (left and middle - morphological viability of various cysts) and anterior part of $\mathrm{J}_{2}$ juvenile (right) of Globodera artemisiae $($ bar $=10 \mu \mathrm{m})$

u osobników młodocianych znajdujących się w cystach pochodzących z terenu województwa świętokrzyskiego był zaokrąglony i lekko spłaszczony (rys. 2).

Cechy morfologiczne cyst i osobników młodocianych gatunków G. artemisiae i G. millefolii stwierdzonych podczas badań były zgodne z opisem podanym w literaturze (Subbotin i wsp. 2010; Dobosz i wsp. 2013). Należy jednocześnie nadmienić, że u mątwików z rodzaju Globodera, w tym u notowanych w Polsce gatunków G. artemisiae, G. millefolii, G. pallida i G. rostochiensis obserwuje się zmienność kształtu guzików sztyletu, która może utrudnić identyfikację nicieni metodą morfologiczno-metryczną (Dobosz i wsp. 2013; Karnkowski i wsp. 2015). 
Podczas analiz molekularnych, po zastosowaniu trawienia restrykcyjnym enzymem $B s h 1236$ I dla gatunku G. artemisiae uzyskano produkty reakcji PCR-RFLP na oczekiwanej wysokości $\sim 860, \sim 540, \sim 320, \sim 190 \mathrm{i} \sim 110 \mathrm{pz}$ (rys. 3), a dla G. millefolii przy trawieniu enzymem AluI na wysokości $\sim 1012$ pz, a przy trawieniu enzymem Hinfl na wysokości $\sim 888$ pz (rys. 4). Przy trawieniu enzymem AluI nie uzyskano jednak wyraźnego obrazu produktu reakcji
PCR-RFLP na wysokości $\sim 14$ pz. Wyniki sekwencjonowania analizowane na podstawie danych umieszczonych w bazie NCBI wykazały 100\% podobieństwa z sekwencją AY599498.1 przypisaną do gatunku $G$. achilleae obecnie zsynonimizowanego z $G$. millefolii oraz $99 \%$ podobieństwa z sekwencją HQ260407.1 przypisaną do gatunku G. millefolii.
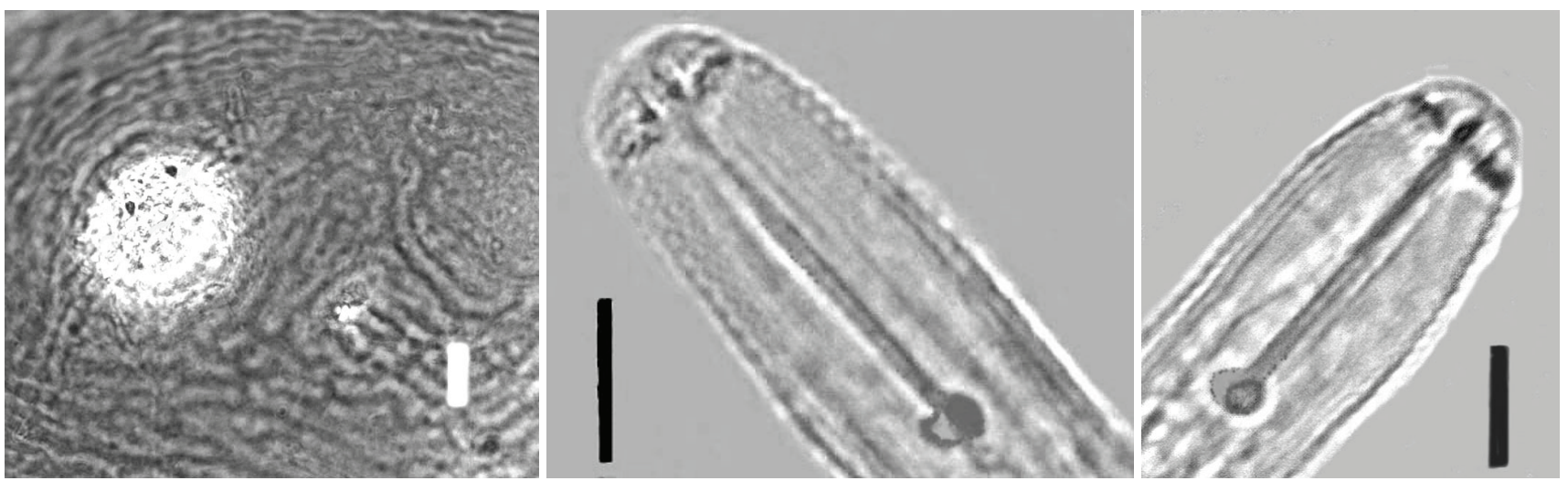

Rys. 2. Okolice wulwy i odbytu cysty (po lewej) oraz przednia część ciała osobnika młodocianego $\mathrm{J}_{2}$ (w środku i po prawej) Globodera millefolii (skala wielkości $=10 \mu \mathrm{m}$ )

Fig. 2. The area of fenestra and anus of cyst (left) and anterior part of $\mathrm{J}_{2}$ juvenile (middle and right right) of Globodera millefolii $($ bar $=10 \mu \mathrm{m})$

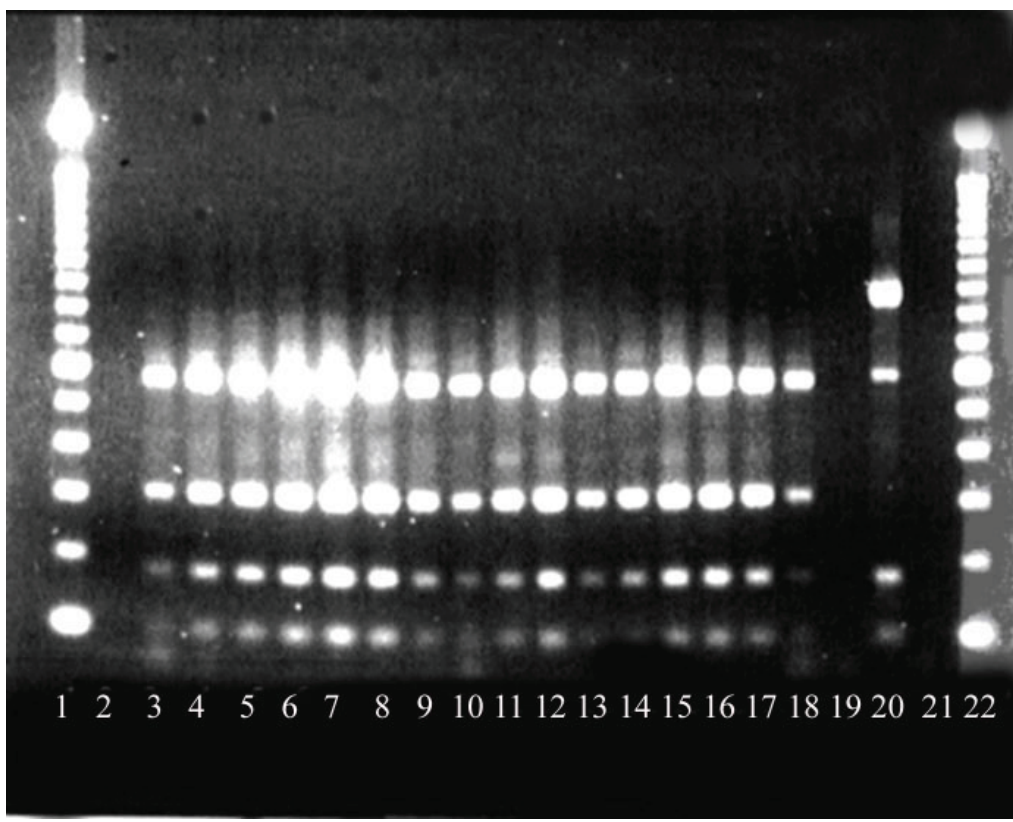

Rys. 3. Rozdział elektroforetyczny produktów reakcji RFLP trawionych enzymem Bsh 1236 I (metoda według Thiéry i Mugniéry 1996): 2 - materiał z badanej próbki Globodera artemisiae: brak produktu, 3-18 - materiał z badanej próbki: G. artemisiae, 19 - pozytywna kontrola trawienia dla G. pallida (brak produktu), 20 - pozytywna kontrola trawienia dla G. rostochiensis, 21 - kontrola negatywna PCR (kontrola odczynnikowa, bez matrycy DNA), 1, 22 - marker DNA (100 bp DNA Ladder ${ }^{\mathrm{TM}}$, Invitrogen)

Fig. 3. Amplified PCR products from the sample digested by enzyme Bsh 1236 I (PCR-RFLP method by Thiéry i Mugniéry 1996): 2 - material from the tested sample Globodera artemisiae: no product, 3-18 - material from the tested sample: G. artemisiae, 19 - positive digestion control control for G. pallida (no product), 20 - positive digestion control for G. rostochiensis, 21 - PCR negative control (reagent control, without DNA template), 1, 22 - DNA marker (100 bp DNA LadderTM, Invitrogen) 


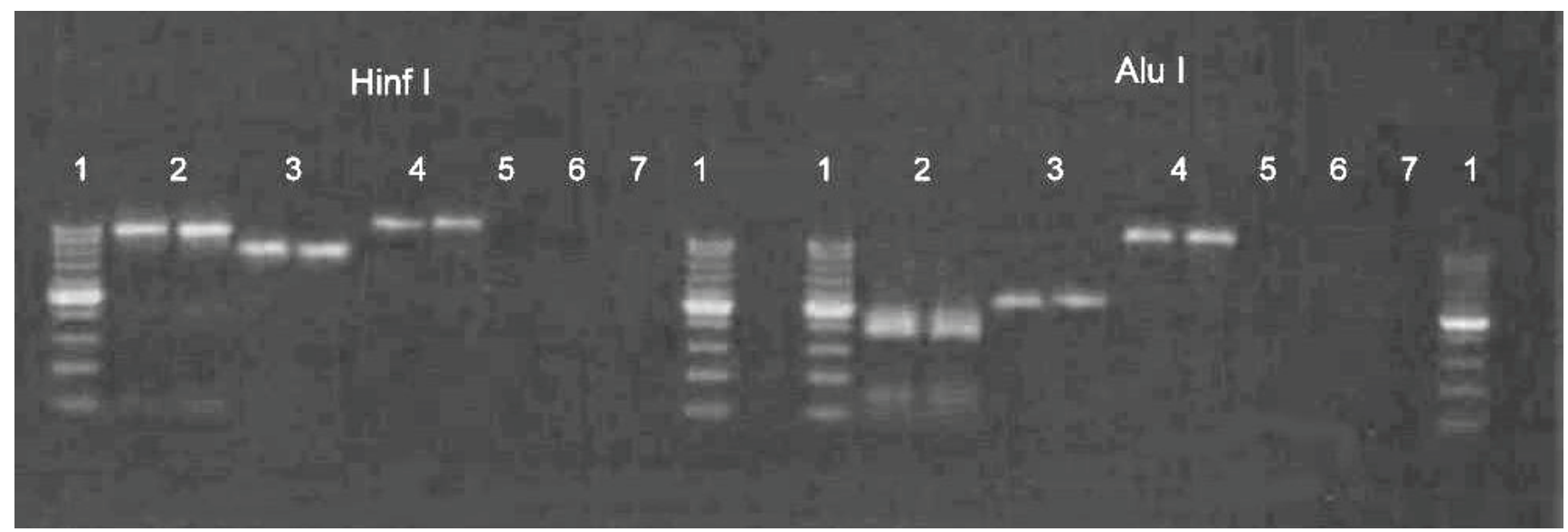

Rys. 4. Rozdział elektroforetyczny produktów reakcji RFLP trawionych enzymami Hinfl i AluI (metoda według Širca i wsp. 2010): 4 - materiał z badanej próbki: Globodera millefolii, 2 - pozytywna kontrola trawienia dla G. rostochiensis, 3 - pozytywna kontrola trawienia dla G. pallida, 5 - kontrola negatywna amplifikacji (kontrola odczynnikowa, bez matrycy PCR), 6 - kontrola negatywna trawienia (kontrola odczynnikowa, bez matrycy PCR), 7 - kontrola negatywna elektroforezy (woda z 6x Loading Buffer Blue ${ }^{\mathrm{TM}}$, EURx), 1 - marker DNA (Perfect 100-1000 bp DNA Ladder ${ }^{\mathrm{TM}}$, EURx)

Fig. 4. Amplified PCR products from the sample digested by enzymes Hinfl i AluI (PCR-RFLP method by Širca et al. 2010): 2 material from the tested sample: Globodera millefolii, 2 - positive digestion control for G. rostochiensis, 5 - positive digestion control for G. pallida, 21 - negative amplification control (reagent control, without DNA template), 6 - negative digestion control (reagent control, without DNA template), 7 - negative electrophoresis control (water with 6x Loading Buffer Blue ${ }^{\mathrm{TM}}$, EURx), 1 - DNA marker (Perfect 100-1000 bp DNA LadderTM, EURx)

Dla porównania, obecność gatunku G. rostochiensis stwierdzono w 1228 próbkach $(0,46 \%)$ pobranych na terenie wszystkich województw oprócz dolnośląskiego, a $G$. pallida w 2 próbkach $(0,0008 \%)$ pobranych na terenie województwa opolskiego i podkarpackiego. Próbki, w których stwierdzono występowanie gatunków G. artemisiae i G. millefolii stanowiły 3,34\% ogółu próbek, w których stwierdzono obecność cyst mątwików z rodzaju Globodera z żywą zawartością.

\section{Wnioski / Conclusions}

1. Wyniki badań wskazują, że poza cystami gatunków G. rostochiensis i G. pallida, w próbkach gleby i podłoży pobranych na terytorium kraju mogą występować, choć w znacznie mniejszym nasileniu, cysty gatunków G. artemisiae i G. millefolii.

2. Zważywszy na żywicieli $G$. artemisiae i $G$. millefolii należy uznać, że występowanie cyst tych mątwików w glebie pól uprawnych jest najprawdopodobniej rezultatem rozwoju nicieni na roślinach $\mathrm{z}$ rodziny Astera- ceae, rosnących na tych polach jako chwasty. Identyfikacja mątwików stwierdzanych podczas urzędowej kontroli występowania mątwików tworzących cysty na ziemniaku powinna opierać się na szczegółowej analizie cech morfologicznych cyst i osobników młodocianych nicieni, a w miarę potrzeb należy potwierdzać wyniki identyfikacji z zastosowaniem testów molekularnych.

3. Populacja gatunku G. millefolii stwierdzona na terenie województwa świętokrzyskiego jest pierwszą populacją na terenie Polski, dla której wykonano identyfikację z zastosowaniem testów molekularnych (PCR-RFLP) i przeprowadzono sekwencjonowanie produktu PCR.

\section{Podziękowanie / Acknowledgements}

Autorzy pragną podziękować ANSES Laboratoire de la Santé des Végétaux, w Le Rheu (Francja) za udostępnienie metodyki identyfikacji $G$. artemisiae oraz konsultacje w tym zakresie.

\section{Literatura / References}

Brzeski M.W. 1998. Nematodes of Tylenchina in Poland and Temperate Europe. Muzeum i Instytut Zoologii Polskiej Akademii Nauk, Warszawa, 398 pp.

Bulman S.R., Marshall J.W. 1997. Differentiation of Australasian potato cyst nematode (PCN) populations using the polymerase chain reaction (PCR). New Zealand Journal of Crop and Horticultural Science 25 (2): 123-129. DOI: 10.1080/01140671.1997.9513998.

Dobosz R., Budziszewska M., Nowaczyk K., Obrępalska-Stęplowska A. 2013. Diagnostyka nicieni pasożytów roślin objętych przepisami kwarantanny. Instrukcja rozpoznawania gatunków z rodzaju Globodera. Wyd. 2. Instytut Ochrony Roślin - Państwowy Instytut Badawczy, Poznań, 16 ss.

Dobosz R., Obrępalska-Stęplowska A., Nowaczyk K., Kornobis S. 2008. Diagnostyka nicieni pasożytów roślin objętych przepisami kwarantanny. Instrukcja rozpoznawania gatunków z rodzaju Globodera. Instytut Ochrony Roślin - Państwowy Instytut Badawczy, Poznań, 16 ss. 
Golden A.M., Klindić O. 1973. Heterodera achilleae n. sp. (Nematoda: Heteroderidae) from Yarrow in Yugoslavia. Nematology 5 (3): 196-201.

Karnkowski W. 2006. Nicienie podlegające obowiązkowi zwalczania - wykrywanie i oznaczanie. Główny Inspektorat Ochrony Roślin i Nasiennictwa, Warszawa, 160 ss.

Karnkowski W., Butrymowicz J., Saldat M., Kaczmarek A. 2015. Wyniki badań składu gatunkowego mątwików tworzących cysty na ziemniaku prowadzonych przez Państwową Inspekcję Ochrony Roślin i Nasiennictwa w latach 2009-2013 z zastosowaniem metody morfologiczno-metrycznej oraz testów molekularnych. [Morphometric and molecular analyses of the composition of potato cyst nematodes carried out by the State Plant Health and Seed Inspection Service during the years 2009-2013]. Progress in Plant Protection 55 (3): 255-262. DOI: 10.14199/ppp-2015-045.

Karnkowski W., Kaczmarek A., Dobosz R., Wieczorek P., Obrępalska-Stęplowska A. 2011. Wystąpienie mątwika agresywnego Globodera pallida (Stone, 1973) Behrens, 1975 (Nematoda: Heteroderidae) na terytorium Polski. [Occurrence of the white potato nematode Globodera pallida (Stone, 1973) Behrens, 1975 (Nematoda: Heteroderidae) on the territory of Poland]. Progress in Plant Protection/Postępy w Ochronie Roślin 52 (4): 1087-1092. DOI: 10.14199/ppp-2012-188.

Kirjanova E.S., Krall E. 1965. Heterodera millefolii n. sp. (Nematoda: Heteroderidae). Izvestiya Akademii Nauk Estonskoi SSR. Seriya biologicheskaya 14: 325-328. (In Russian).

OEPP/EPPO 2009. EPPO Standards. PM 7/40(2) Globodera rostochiensis and Globodera pallida. Bulletin OEPP/EPPO Bulletin 39: $354-368$.

OEPP/EPPO 2013. EPPO Standards. PM 7/40(3) Globodera rostochiensis and Globodera pallida. Bulletin OEPP/EPPO Bulletin 43: 119-138. DOI: 10.1111/epp.12025.

Širca S., Geric Stare B., Strajnar P., Urek G. 2010. PCR-RFLP diagnostic method for identifying Globodera species in Slovenia. Phytopathologia Mediterranea 49 (3): 361-369.

Subbotin S.A., Mundo-Ocampo M., Baldwin G.B. 2010. Systematics of Cyst Nematodes (Nematoda: Heteroderinae), Part A. p. 107-177. In: "Nematology Monographs and Perspectives Volume 8A" (Series Editors: D.J. Hunt, R.N. Perry). Leiden, The Netherlands, Brill, 351 pp.

Thiéry M., Mugniéry D. 1996. Interspecific rDNA restriction fragment length polymorphism in Globodera species, parasites of Solanaceous plants. Fundamental and Applied Nematology 19 (5): 471-479.

Zouhar M., Rysanek O., Kocova M. 2000. Detection and differentiation of the potato cyst nematodes Globodera rostochiensis and Globodera pallida by PCR. Plant Protection Science 36: 81-84. 